\title{
The role and influence of advertising and public authorities on the health-related behaviours development among lower secondary school students
}

\begin{abstract}
Introduction. Adolescence is the period during which a man shapes his habits, attitudes and health behaviours. This is the time when man searches authorities who can be the role models for young people. According to the definition, authority is a social recognition, prestige of individuals, groups and social institutions based on the reputable values of a given society

Aim. The aim of the study was to determine what elements of advertising affect the health behaviours of young people and to what degree.

Matherial and methods. The study was conducted among 187 students of lower secondary school, inhabitants of the city of Kielce. The surveyed group consisted of 45 students aged 14, 78 at the age of 15, and 57 at the age of 16. Among lower secondary school students, $48 \%$ were girls, while $52 \%$ were boys. An anonymous questionnaire was used to achieve the aim of this study. The questionnaire consisted of 19 closed questions.

Results. Fifty-six percent of girls and $45 \%$ of boys believe that advertising has an impact on people. For the large part of girls $(33 \%)$ the most important was the musical setting and for $31 \%$ of boys, concrete facts and information about the product were essential. What is more, $72 \%$ of girls and $50 \%$ boys pay attention to the information about famous people presented in the mass media.

Disscusion. Sixty percent of respondents believe that stimulants are attractive. Similarly, the research conducted by Borzucka-Sitkiewicz shows that the influence of peers and fashion are the most important factors influencing the decisions to reaching for cigarettes. According to own research, $72 \%$ of respondents aged 14-16, draw attention to the information about well-known people placed in the mass media. Similar results are indicated in the study "Stars and rumours", according to which $86 \%$ of respondents confirmed they were interested in this subject.

Conclusions. Smoking cigarettes and consumption of alcohol by young people are the components of family, peers and the media influence. In addition, public awareness-raising campaigns related to health topics can have the impact on the lifestyle of young people.
\end{abstract}

Keywords: health education, health determinants, lower high school, health-related behaviours.

DOI: $10.12923 /$ j.0044-2011/123-3/a.05

\section{INTRODUCTION}

The period of adolescence is a special phase in the man's life, and in the whole process of his development. This is a transitional period between childhood and adulthood. However, growing up is not a simple process. It progresses in a complex and dynamic way, while many radical changes take place over a short period of time [1].

Adolescence is a period of the most intense pace of growth. There are changes in the structure and proportions of the body, as well as in a male's and female's bodies. At the same time the anatomy and functioning of all systems, especially the endocrine system are changing [2].

During puberty, the appearance is changing, indicating such features as greasy hair, increased sweating and acne. There are also changes in mental development, expressing the improvement of cognitive functions such as memory, perception, learning, attention, reasoning, thinking and the concept formation. The development of these features affect the morality and control of emotions, as well as determine own identity and worldview. Most of the mental changes that take place during puberty affect the direction and the course of social activity. During this period, there are also observed changes in the way of thinking from an individual to a more abstract and thus young people are able to foresee the consequences of their actions, and identify cause-and-effect relationships [3].

Another important aspect of the growing up process is the development of emotional maturity, which plays a particularly important role among adolescents. Increased emotionality during this period is associated with changes in the field of physiological sphere and with the active participation of young people in a social life [4]. 
The characteristic features of the emotional life, concerning particularly young people are:

- the intensity of emotional experience that can achieve a high degree of tension;

- emotionlessness - young people are often not able to explain the reasons for their mood or emotions. While at one moment, the young man is cheerful and happy, another time - everyting irritates or annoys him/her;

- emotional instability, which means that young people change moods easily (from hope to despair, from enthusiasm to discouragement, from joy to sadness);

- once a young man shies away from others, and another time he wants to be among other people, once is good, sometimes is cruel (this phenomenon is called "feelings ambivalence") [5].

During puberty, a networking with peers is very important. Youth widen the circle of their close and distant colleagues and friends. Friendship becomes a significant aspect of relations between young people. Adolescents feel the need to share experiences and feelings, the need of acceptance, but they are also looking for support and security. Young people often choose friends with similar interests, such as music, sports, and dance. The result is that they get involved in certain areas and thus, maintain those connections by sharing the same interests [3].

In addition, peer groups provide certain models of behaviours and the lifestyles. Examples of some forms of behaviour that are popular among teenagers and make it possible to join social groups are fascination with appearance, dress, a music band or an actor [4].

Adolescence is a period of rebellion against the values preferred by adults. Youth mutiny against the orders, prohibitions, adopted rules and standards. Teenagers are susceptible to mass culture that influences their behaviour, values, motivations and goals [6].

One of the following aspects of the human development process is the creation of his personality. A young man becomes interested in his own personality features and compares himself with friends, which results in the separation of his individuality against a social group which he lives in. In the development of self-awareness, the evaluations by others as well as the self-esteem are very important and the knowledge of a young man about himself depends on the evaluation of other people. Young people often pass through the so-called "identity crisis". Strong self-esteem, knowledge of own strengths, weaknesses, and opportunities is the result of a well-resolved identity crisis [7].

\section{AIM}

The aim of this study was to determine to what degree and what elements of advertising affect the health behaviours of young people. The aim was also to determine to what extent social behaviours of public authorities shape these behaviours.

\section{MATERIAL AND METHODS}

The study included 187 lower high school students at the age of 14 (45 students), 15 (78 students) and 16 (57 students). Among the respondents, $48 \%$ were girls and 52\% were boys. Sampling unit was the class. Sampling scheme assumed a simple random selection. The classes were selected from among all lower high school grade levels, two of each. As a result of the study 187 questionnaires were obtained out of which 180 were passed to the further study.

ThesurveywasconductedinApril2012attheschoolinKielce, with approval of the schoolmaster. The respondents, all residents of Kielce, were informed about the anony-mity of the study.

The research was carried out using a questionnaire survey designed by authors. This method is a research technique, consisting of meeting in a certain group of people associated with the test category (class) and distribution of the questionnaires to fill them out. In this case, the interviewer is limited to the presentation of the aims of the study and explanation of the rules of answering questions. [8]

The questionnaire consisted of 19 questions, related to the role of the media in making health-related decisions among teenagers.

\section{RESULTS}

Question 1: "Do you think that alcohol advertising has an impact on people? " Most girls (56\%) and a great part of boys $(45 \%)$ believe that these advertisements have an impact on people. The highest percentage of positive answers was among teenagers at the age of 15 , both boys and girls. Forty-seven percent of all respondents suppose that alcohol advertising affects people, $40 \%$ that it has no effects, while the remaining (13\%) have no opinion (Table 1).

TABLE 1. Impact of alcohol advertising on people.

\begin{tabular}{ccccc}
\hline \multirow{2}{*}{ Sex } & \multirow{2}{*}{ Age } & \multicolumn{3}{c}{ Impact of alcohol advertising on people } \\
\cline { 2 - 5 } & & Yes & No & No opinion \\
\hline \multirow{3}{*}{ Girls } & 14 years & $13 \%$ & $9 \%$ & $2 \%$ \\
\cline { 2 - 5 } & 15 years & $27 \%$ & $13 \%$ & $5 \%$ \\
\cline { 2 - 5 } & 16 years & $16 \%$ & $9 \%$ & $6 \%$ \\
\hline \multirow{3}{*}{ Boys } & Total & $56 \%$ & $31 \%$ & $13 \%$ \\
\cline { 2 - 5 } & 14 years & $16 \%$ & $6 \%$ & $4 \%$ \\
\cline { 2 - 5 } & 15 years & $19 \%$ & $17 \%$ & $6 \%$ \\
\cline { 2 - 5 } & 16 years & $10 \%$ & $18 \%$ & $4 \%$ \\
\hline
\end{tabular}

Source: own research.

Question 2: "What part of advertisement attracts your attention the most?". For the large part of girls (33\%) the most important was the musical setting and for $31 \%$ of boys concrete facts and information about the product were essential. Analysing the responses of a whole group, 25\% of young people indicated the graphics, colour and visual elements, $23 \%$ - the specific facts and figures about the product, $22 \%$ - participation of famous people, $22 \%$ - the musical setting and the remaining subjects chose other means of advertising (Table 2). 
TABLE 2. Parts of advertisement with attract attention the most.

\begin{tabular}{|c|c|c|c|c|c|c|}
\hline \multicolumn{7}{|c|}{ Parts of advertisement with attract attention the most } \\
\hline Sex & Age & $\begin{array}{c}\text { Musical } \\
\text { setting }\end{array}$ & $\begin{array}{l}\text { Graphics, } \\
\text { colour } \\
\text { and visual } \\
\text { elements }\end{array}$ & $\begin{array}{c}\text { Participation } \\
\text { of famous } \\
\text { people }\end{array}$ & $\begin{array}{c}\text { The specific } \\
\text { facts and } \\
\text { figures } \\
\text { about } \\
\text { the product }\end{array}$ & Other \\
\hline \multirow{4}{*}{ Girls } & 14 years & $7 \%$ & $5 \%$ & $8 \%$ & $2 \%$ & $2 \%$ \\
\hline & 15 years & $10 \%$ & $16 \%$ & $10 \%$ & $7 \%$ & $0 \%$ \\
\hline & 16 years & $16 \%$ & $2 \%$ & $8 \%$ & $6 \%$ & $1 \%$ \\
\hline & Total & $33 \%$ & $23 \%$ & $26 \%$ & $15 \%$ & $3 \%$ \\
\hline \multirow{4}{*}{ Boys } & 14 years & $0 \%$ & $12 \%$ & $3 \%$ & $9 \%$ & $2 \%$ \\
\hline & 15 years & $5 \%$ & $7 \%$ & $12 \%$ & $11 \%$ & $6 \%$ \\
\hline & 16 years & $6 \%$ & $7 \%$ & $2 \%$ & $12 \%$ & $4 \%$ \\
\hline & Total & $12 \%$ & $27 \%$ & $17 \%$ & $31 \%$ & $13 \%$ \\
\hline
\end{tabular}

Source: own research.

Figure 1 shows that $35 \%$ of girls and $52 \%$ of boys indicate that TV advertising annoys them. Positive attitude towards the TV advertising was declared by $7 \%$ of girls and $5 \%$ of boys.

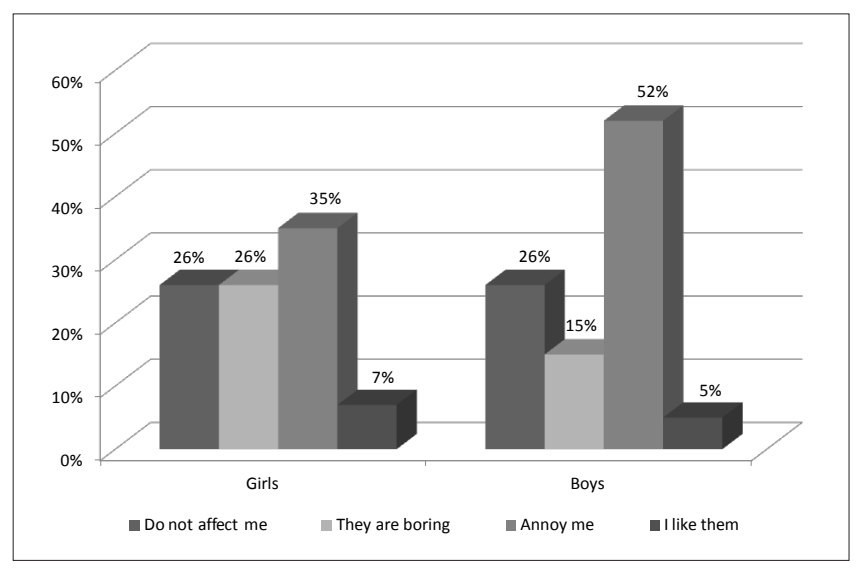

FIGURE 1. Attitude towards TV advertising.

Source: own research.

In question 4: "Do you pay attention to the information about famous people in the magazines, on the television or on the Internet?" the largest group of teenagers pointed out the answer "yes, sometimes" (72\% of girls and 50\% boys). However, significantly more boys (40\%) compared to girls (15\%) do not pay attention to these types of information.

Respondents, who answered question 4 affirmatively, were asked to indicate what kind of information about famous people attracts their attention the most. The girls at the age of $14(18 \%)$ pay the greatest concern to the public comments on the lifestyle and behaviour, while girls at the age of $15(14 \%)$ and $16(12 \%)$ are most interested in the private lives of famous people. However, boys at the age of $14(11 \%)$ most often pay attention to the professional life of well-known people, at the age of $15(20 \%)$ to a private life, but at the age of $16(11 \%)$ indicate other types of information. Considering all age groups, girls are most interested in comments related to the celebrity lifestyle (34\%), while boys $(30 \%)$ in other kinds of information.
In question 6, the youth was asked "Do you think the photographs of well-known people, smoking cigarettes or drinking alcohol (in the press or on the Internet) have an impact on health-related decisions?" Forty-nine percent of girls believe that these images affect all users, 34\% said "no", while the remaining $(17 \%)$ had no opinion. The boys answered similarly. Forty-eight percent of young men think that such images are reflected in the behaviour of people, 35\% said "no", and the rest of that group (17\%) had no opinion. A significant proportion of all respondents (49\%) agreed that such images affect all users, and only $34 \%$ indicated that they have no effect. Table 3 shows the structure of the responses.

TABLE 3. Impact on health-related decisions of the photographs of wellknown people who smoke cigarettes or drink alcohol (in the press or on the Internet).

\begin{tabular}{|c|c|c|c|c|}
\hline \multirow[t]{2}{*}{ Sex } & \multirow[t]{2}{*}{ Age } & \multicolumn{3}{|c|}{$\begin{array}{l}\text { Impact on health-related decisions } \\
\text { of the photographs of well-known peopl } \\
\text { who smoke cigarettes or drink alcohol } \\
\text { (in the press or on the Internet) }\end{array}$} \\
\hline & & Yes & No & No opinion \\
\hline \multirow{4}{*}{ Girls } & 14 years & $14 \%$ & $6 \%$ & $5 \%$ \\
\hline & 15 years & $16 \%$ & $22 \%$ & $6 \%$ \\
\hline & 16 years & $19 \%$ & $6 \%$ & $7 \%$ \\
\hline & Total & $49 \%$ & $34 \%$ & $17 \%$ \\
\hline \multirow{4}{*}{ Boys } & 14 years & $16 \%$ & $5 \%$ & $4 \%$ \\
\hline & 15 years & $19 \%$ & $18 \%$ & $5 \%$ \\
\hline & 16 years & $13 \%$ & $12 \%$ & $7 \%$ \\
\hline & Total & $48 \%$ & $35 \%$ & $17 \%$ \\
\hline
\end{tabular}

Source: own research.

Young people, who answered question 6 affirmatively, were asked to determine the kind of impact, which is imposed by photos of celebrities smoking cigarettes or drinking alcohol, published in the press and on the Internet. Fifty percent of girls and $51 \%$ of boys decided that those photos increased the desire to reach for alcohol or cigarettes. Twenty-four percent of all respondents believe that the spread of information about the celebrities' addictions become one of the excuse concerning health-related behaviour for young people. Seventeen percent of respondents believe that such images have an impact on the decision to choose a particular type of stimulants.

Question 8: "Does the information about the problems of famous people associated with alcohol abuse (arrest, beatings, and car accidents) published in the media affect you?" Sixty-four percent of all respondents indicated that such information does not have any impact on them; however, 36\% admitted that they it has some influence. The most vulnerable groups to the impact of information about the celebrities' problems were girls at the age of $15(19 \%)$ and boys at the age of $14(10 \%)$ and $15(9 \%)$. The results are presented in the Table 4.

Respondents, who are affected by alcohol abuse problems of famous people, were asked to assess what kind of impact it was. Forty percent of girls and $31 \%$ of boys reading such publications do not reach for alcohol. Considering all teenagers, spreading of information about the alcohol problems 
TABLE 4. Impact on health-related decisions of the photographs of wellknown people who smoke cigarettes or drink alcohol (in the press or on the Internet).

Affect of the published in media information about the problems of famous people associated with alcohol abuse (arrest, beatings, car accidents)

\begin{tabular}{ccccc}
\cline { 3 - 5 } & & $\begin{array}{c}\text { Yes, } \\
\text { always }\end{array}$ & $\begin{array}{c}\text { Yes, } \\
\text { sometimes }\end{array}$ & No \\
\hline \multirow{3}{*}{ Girls } & 14 years & $1 \%$ & $6 \%$ & $17 \%$ \\
\cline { 2 - 5 } & 15 years & $1 \%$ & $19 \%$ & $24 \%$ \\
\cline { 2 - 5 } & 16 years & $3 \%$ & $7 \%$ & $21 \%$ \\
\hline \multirow{3}{*}{ Boys } & Total & $6 \%$ & $31 \%$ & $63 \%$ \\
\cline { 2 - 5 } & 14 years & $2 \%$ & $10 \%$ & $14 \%$ \\
\cline { 2 - 5 } & 15 years & $5 \%$ & $9 \%$ & $29 \%$ \\
\hline & 16 years & $4 \%$ & $4 \%$ & $23 \%$ \\
\hline
\end{tabular}

Source: own research.

of well-known people usually does not coach them to drinking alcohol (36\%) and is a kind of warning for them (27\%). However, $18 \%$ of respondents more often reach for alcohol after reading about alcohol abuse by famous people.

Question 10 aimed to identify the respondents' opinions about the attractiveness of stimulants such as cigarettes and alcohol among young people ("Stimulants such as alcohol and cigarettes are: attractive/unattractive for young people/I have no opinion). In the group of girls, $9 \%$ of 14 -year-olds, $23 \%$ of 15 -year-olds and $28 \%$ of 16 -year-olds believe that cigarettes and alcohol are attractive to young people. Eighteen percent of boys aged 14, 22\% aged 15 and $17 \%$ at the age of 16 agree with the girls. However, only $10 \%$ of girls and $21 \%$ of boys recognised these stimulants as not attractive. The structure of the responses is presented in Figure 2.

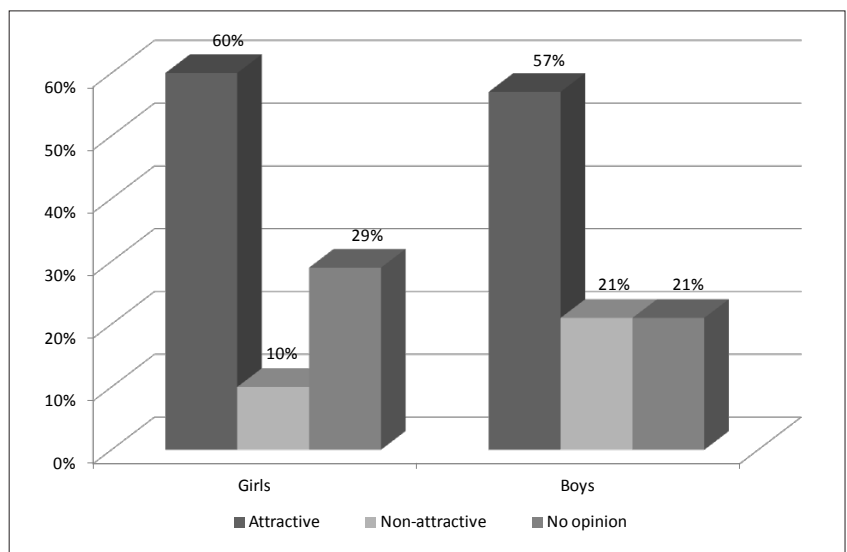

FIGURE 2. Attractiveness of stimulants such as alcohol and cigarettes. Source: own research.

Question 11 allowed determining some reasons for attractiveness of alcohol and drugs among young people. Respondents, who consider drugs to be attractive (59\%) most often showed a possibility to chill out (28\%) and assurance of the peers' acceptance as the main reasons. Apart from abovecited factors, young people also pointed out that stimulants increase their self-confidence (15\%), help not to think about problems $(15 \%)$ and that they are simply trendy (15\%).

Question 12: "Does the cult of the slim and nice-looking body popularised by the media affect your lifestyle?" The research shows that promoting of the ideal body shape has a greater impact on the behaviour of girls $(65 \%)$ than boys (29\%). In the group of girls, the respondents at the age of 15 (29\%) were the most vulnerable to such information. This activity is neutral for $17 \%$ of girls and $33 \%$ of boys. The cult of ideal body propagated in the media affects the changes in the respondents' lifestyle, mainly in the areas of nutrition $(36 \%)$ and physical activity (39\%). Definitely more girls $(41 \%)$ compared to boys $(23 \%)$ made changes in the diet. Figure 3 shows the results.

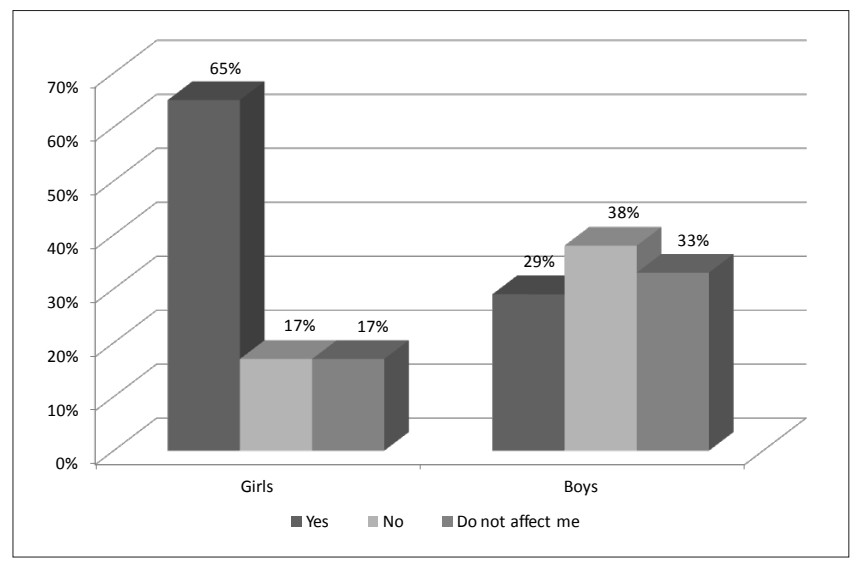

FIGURE 3. Affect of the cult of the slim and nice-looking body popularised by the media on own lifestyle.

Source: own research.

Questions 13 ("In what areas of your life there is a change of these behaviour?"), 14 ("What is the health-related change in behavior ?") and 15 ("Has the intensity of your physical activity changed?") related to changes in the lifestyle. Changes in a diet, both in the group of girls $(68 \%)$ and boys $(33 \%)$, were most often associated with the introduction of a rational, balanced diet. Fourteen percent of this group use the diet described in the press and on the Internet, another group of respondents $-14 \%$ go on hunger strike. Teenagers who pledged the changes in the physical activity chiefly do fitness (58\% of young people). Boys more often exercise at the gym (61\%) than girls $(50 \%)$.

Question 16: "Does the problem of anorexia and bulimia among models and celebrities popularised by the media, have an impact on your attitude to eating?". Twenty-eight percent of all respondent indicatedthat this information coax them to eat healthy food. Ten percent of girls and $10 \%$ of boys pointed out that they have no impact, and $12 \%$ of respondents do everything to lose weight.

Question 17: "Have you ever seen a social campaign concerning health?" Seventy-eight percent of all respondents have seen this type of campaign, although $24 \%$ of girls and $30 \%$ of boys have not seen this form of social advertising yet.

Question 18 concerned the knowledge about the subject of that kind of campaign. The greatest percentage of young people has seen the social campaigns concerning smoking (31\%) and alcohol (28\%). Some of girls (25\%) and boys $(17 \%)$ have also seen diet campaigns. 
Question 19: "Did any social campaign concerning health cause any changes in your behaviour from negative to positive?" It turned out that the awareness-raising campaigns have a greater impact on behaviour change among girls $(54 \%)$ than boys $(37 \%)$. Sixty-three percent of boys, especially in the group of 15 year-olds indicated that those campaigns do not change their behaviours (Figure 4).

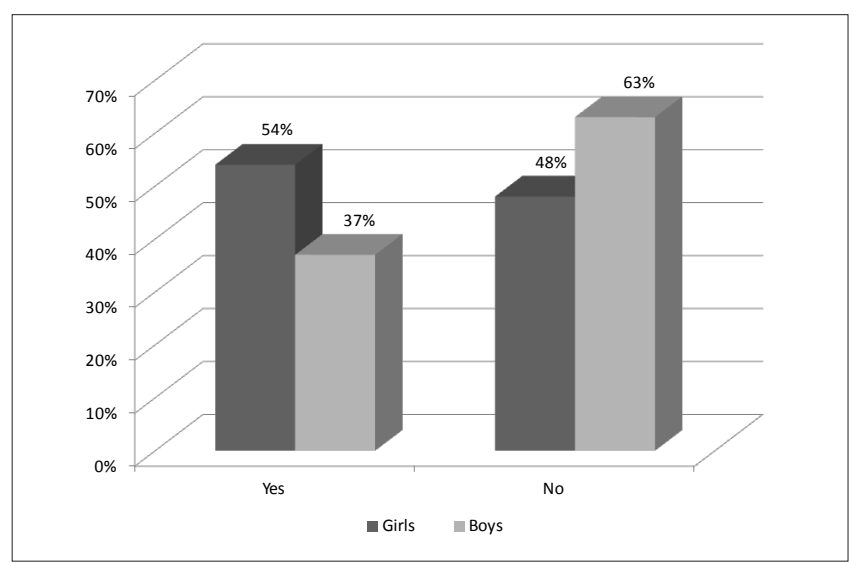

FIGURE 4. Changes in your behaviour from negative to positive caused by social campaign concerning health.

Source: own research.

\section{DISCUSSION}

Stimulants, such as cigarettes and alcohol are common among adolescents. As there was presented in the results of own research, $60 \%$ of respondents indicated that stimulants are attractive among young people. The largest number of young people pointed out a possibility to chill out and assurance of the peers' acceptance as the reasons of the cigarettes and alcohol attractiveness. Similarly, a study by BorzuckaSitkiewicz pointed at the influence of peers and fashion as the main factors contributing to smoking [9].

According to Mazur Woynarowska, adolescents believe that smoking helps in stressful situations, keeps a shapely body and increases self-confidence [10].

As for the impact on the attitudes of young people towards alcohol consumption, the study by Pisarska et al. indicates that the environment and the peers' pressure are most important [11].

The study by Borzucka-Sitkiewicz shows that young people observing adults conclude that alcohol consumption is attractive. In addition, for many teenagers this type of stimulants is a source of joy and it facilitates social contacts. Research by Borzucka-Sitkiewicz also shows that young people most often reach for a beer. The choice of this drink is probably the result of the impact of advertising directed to young people [9].

Television, radio, newspaper and the Internet advertising are seen by almost every consumer and create the need for a specific product. The results of the author's survey show that most young people believe that the advertising have a significant impact on people, however, their attitude towards advertising is negative. The study "Attitudes of Polish consumers towards advertising" by Kośmider-Cichomski shows that only every fifth 15 -year-old subject is critical towards advertising. This difference may result from the fact that young people, in spite of their negative attitudes towards advertising, find in them the esthetic, artistic, or humorous values, which attract their attention.

Advertising is also a source of information that helps young consumers to make the decision about purchasing a particular item. In addition, the advertising creators often use well-known and much-loved people to promote the product, which also arouse interest among young people [12].

The mass media are the dominant clutural mainstream, which is in a contact with the modern youth. The contents of the press, television and the Internet message have a significant impact on the perception of the world, often shaping the identity of the young generation. According to the literature research, $90 \%$ of people aged 15-29 are readers of the press [13].

With regard to the Internet, the network users are mainly young people. Above $51 \%$ of people aged $7-15$ and $87 \%$ aged 16-24 use the Internet. In addition, three out of four Internet users use the traditional media such as television, radio and newspapers via the Internet [14].

The mass media could be a good source of information, if the recipients used them advisedly. Unfortunately, children and young people are vulnerable to the effects of the media. They have not formed a system of values and attitudes yet and do not have the knowledge to be able to assess messages accurately [15].

Furthemore it is noticed that information content in the press, on television or on the Internet are replaced by entertainment. According to own research attention of $72 \%$ of respondents aged 14-16 is attracted to the information about famous people published in the mass media. The research "Stars and rumors" reveals similar results, according to which $86 \%$ of respondents indicate that they are interested in this subject [16].

The results of the authors' study suggest that young people are most interested in information related to the family $(30 \%)$ and professional life $(17 \%)$ of celebrities and comments about their lifestyle and behaviour (23\%). The "Star Stories" research showed similar data, according to which the most desirable news about famous people are rumours $(45 \%)$, scandals and affairs (30\%), working life (30\%) and family life $(20 \%)$, as well as their opinion about current issues $(25 \%)$ [16]. The main sources of information about celebrities are the Internet, television, and colour magazines. The most likeable rumours online services are "Pudelek" (48\%), "Rumour" (16\%) and "Pleiade" (15\%). There are also many TV programmes with participation of celebrities. The most frequently watched are the following: "I have a talent", "Kuba Wojewódzki" or "Dancing with the Stars" [16].

We can find many articles about the life of well-known people in the press too. The readership surveys show that young women often choose magazines, where they can find information about beauty (84.6\%), fashion (83.3\%) and life of famous people (83.3\%). However, men aged 15-29 are primarily interested in local news $(68.6 \%)$, motorization (65.7\%) and sport (63.6\%) [13].

Among varied information about celebrities in the press or on the Internet, there are those, which present famous people smoking cigarettes and drinking alcohol. Almost half of the respondents $(49 \%)$ believe that the publication of such 
photographs has an impact on making the decisions by the audience. Most of the young people find that these publications are incentives to reach for cigarettes and alcohol, as well as may be a kind of excuse for antihealthy behaviours. On the other hand, the study by Borzucka-Sitkiewicz does not consider the mass media as the most important factor in decision making among teenagers. The difference in these results of the studies may result from the fact that some of young people are not aware of the mass media impact on their decisions [9].

Information about celebrities' problems of alcohol abuse, such as fights, car accidents or arrests, is published in the press as well as on the Internet. A significant part of respondents $(64 \%)$ said that such messages do not have any effects on them. Some of teenagers perceive these information even positively because they are a kind of warning.

The cult of the "ideal" body is amplified and spreaded by the media. The media create standards of attractiveness and determine the socially expected physical characteristics of men and women. The mass media promote a specific pattern of beauty and body shape and many children and young people learn their gender roles from this source [17].

Movies usually present beautiful and thin characters, and pictures published in magazines most often show unrealistic ideal bodies of the models. This phenomenon causes that most people want to change their figure, according to those propagated by the media [18].

As it comes out of own research, the body cult promoted by mass culture has a much greater impact on girls than boys. The study by Izydorczyk and Rybicka-Klimczyk confirms that statement and indicates that the media are an important source of information about the standards of ideal body, especially for teenagers dissatisfied with their bodies [19].

Some of the respondents change their lifestyle under the influence of attractiveness standards promoted in the media. The largest part of the youth introduces new diets designed by a dietician or described in the press, including fastings. Changes in physical activity made by youth predominately rely on the increase in the number of trainings. The study by Kowalczyk, according to which mass culture imposes ideas of fitness and diets, confirms these results [20].

Whenanalysing the impact of the mass media on adolescent lifestyle changes, it can be concluded that this impact has a positive effect on health behaviours of young people. The usage of reasonably balanced diet and increase of physical activity have a favourable effect on health. However, it should be noted that the pressure on pattern of "thinness" can carry a lot of risks associated with eating disorders such as bulimia and anorexia. The problems of anorexia and bulimia among models and celebrities popularized by the media do not affect significantly the youth. Own study showed that discussed subjects do not have positive effects on every fifth person, who does everything to lose weight. However, $28 \%$ of respondents influenced by such information try to eat healthy food. Wojtyla's research also showed that $33 \%$ of teenagers have already been on a diet [21].

Adolescents should be aware that a healthy, balanced diet and physical activity have the most important influence on the support of healthy weight. Public awareness-raising campaigns are one of the forms of social communication which the media use. According to the research, $78 \%$ of respondents have encountered with this form of advertising. Young people knew mainly campaigns on smoking (31\%), alcohol (28\%) and nutrition (21\%). Social advertising is designed to change the attitudes of people, but the study shows that only $54 \%$ of young people change their behaviours from negative to positive. It may be a result of the fact that a creation of awareness-raising campaigns, which affect everyone is almost not possible to do.

\section{CONCLUSIONS}

According to all presented studies, it can be concluded that smoking cigarettes among young people is a component of the family, peers and the media impact. Similar factors affect the decisions related to the consumption of alcohol. However, in the case of alcohol, the great importance is attributed to the advertising. When the above-mentioned factors are considered, it seems to be necessary to conduct some actions in the field of health promotion targeted at creation of positive health behaviour on the family level. Educational activities in the local community provide an opportunity for early modeling of young people health behaviour, which is the preventive action against potential health problems resulting from the impact of other factors (such as advertising) at the later age.

We should be aware that not all exemples shown by parents, peers, the press and television are examples of healthy behaviour. Young people must learn how to make the right health choices. Therefore, it is important to implement health education programs in lower secondary schools. Activities in the school environment, for example joining the Health Promoting School programme, can build young people's health capacity, which combined with the actions developed in the family environment significantly increases the chances of avoiding health risks at different stages of life. Furthermore, campaigns connected with health addressed to teenagers might have an enormuos impact on the young people's lifestyle. These campaigns should be designed with particular care and methodologies adjusted to the needs and capabilities of the target group. Appropriate presentation of health problems or healthy behaviour model in a social campaign can be a part of the wider prevention activities targeted to young people.

\section{REFERENCES:}

1. Jankowska M. Podstawy psychologii. Warszawa: Uczelnia Warszawska im. Marii Skłodowskiej-Curie; 2008,

2. Woynarowska B, Jaczewski A (ed). Dojrzewanie. Warszawa: Wydawnictwo Szkolne i Pedagogiczne; 1982.

3. Żebrowska M. Psychologia rozwojowa dzieci i młodzieży. Warszawa; PWN; 1975. p.3.

4. Turner JS, Helms DB. Rozwój człowieka. Warszawa: PWN;1999.

5. Harwas-Napierała B, Trempała J (ed). Psychologia rozwoju człowieka. Warszawa: PWN; 2000.

6. Melosik Z, Szkudlarek T. Kultura, tożsamość i edukacja - migotanie znaczeń. Kraków: Oficyna Wydawnicza Impuls; 1998.

7. Przetacznik-Gierowska M, Tyszkowska M. Psychologia rozwoju człowieka, Warszawa: PWN; 1996.

8. Nowak S. Metodologia badan społecznych, Warszawa: PWN; 1985. 
9. Borzucka-Sitkiewicz K. Kształtowanie zachowań zdrowotnych w procesie socjalizacji a styl życia młodzieży (w rejonie górnośląskim). Katowice: Wydawnictwo Uniwersytetu Śląskiego; 2005.

10. Woynarowska B, Mazur J, Kowalewska A. Palenie tytoniu. Zdrowie młodzieży szkolnej w Polsce, Warszawa: Wydział Pedagogiczny Uniwersytetu Warszawskiego; 2000.

11. Pisarska A, Borucka A, Okulicz-Kozaryn K, Bobrowski K. Picie alkoholu w wypowiedziach młodzieży w wieku 13-15 lat. [www.ipin.edu.pl]

12. Kosmider-Cichomska A. Postawy konsumentów polskich wobec reklamy. Raport z badań ilościowych. Warszawa: Demoskop Badania Rynkowe i Społeczne; 2000.

13. Polskie Badanie Czytelnictwa. III 2011-II 2012. [www.pbczyt.pl]

14. II Badanie Użytkowników Sieci Internet 2000. [www.badania.krakow. pl/wyniki2000/wyniki.html]

15. Melosik Z. Tożsamość, ciało i władza. Teksty kulturowe jako (kon)teksty pedagogiczne. Poznań - Torun: Wydawnictwo Edytor; 1996.

16. Polskie Badanie Internetu. Gwiazdy i plotki. Badanie użytkowników Internetu - wyciąg $\mathrm{z}$ raportu. [www.pbi.org.pl]

17. Jackson LA. Physical attractiveness: A sociocultural perspective W: T. Pruzinsky, TF. Cash Body Image A Handbook of Theory Research, and Clinical Practice. New York-London: The Guilford Press; 2002. p.13-22.

18. Bordo S. Unbearable Weight: Feminism, Western Culture, and the Body. Oakland: University of California Press; 1995. p. 99-277.

19. Izydorczyk B, Rybicka-Klimczyk A. Środki masowego przekazu i ich rola w kształtowaniu wizerunku ciała u różnicowanych wiekiem życia kobiet polskich (analiza badań własnych). Probl Med Rodz. 2009;9(3):20-32.

20. Kowalczyk I. Uwiezione w ciele - ideał ciała w pismach kobiecych. In: E. Zierkiewicz, I. Kowalczyk. Kobieta w kulturze popularnej. Poznań: Konsola; 2002. p.17-32.

21. Wojtyła A, Bilinski P, Bojar I, Wojtyła C. Zaburzenia odżywiania u polskich gimnazjalistów. Probl Hig Epid. 2011;92(2):327-34.

\section{Informacje o Autorach}

Dr n. med. Dominik OlejNicZaK - adiunkt; mgr Urszula Religion - doktorantka, Katedra i Zakład Zdrowia Publicznego, Warszawski Uniwersytet Medyczny; mgr ANETA PŁusa - absolwentka Warszawski Uniwersytet Medyczny.

\section{Corresponding Author}

Dominik Olejniczak

Katedra i Zakład Zdrowia Publicznego

ul. Banacha 1a, blok F, 02-097 Warszawa

E-mail: dominikolejniczak@op.pl 